\title{
Determination of Optimum Slope Design for Northern Boxcut in Zone 5 Khoemacau Copper Mine, Botswana
}

\author{
Maipelo Gaopatwe, Tefo Kgopana, Bame Molebatsi, Rahul Verma* \\ Department of Mining and Geological Engineering, Botswana International University of Science and Technology, \\ Palapye, Botswana \\ Email: *vermar@biust.ac.bw
}

How to cite this paper: Gaopatwe, M., Kgopana, T., Molebatsi, B. and Verma, R. (2021) Determination of Optimum Slope Design for Northern Boxcut in Zone 5 Khoemacau Copper Mine, Botswana. Open Journal of Geology, 11, 38-48. https://doi.org/10.4236/ojg.2021.112003

Received: January 7, 2021

Accepted: February 19, 2021

Published: February 22, 2021

Copyright $\odot 2021$ by author(s) and Scientific Research Publishing Inc. This work is licensed under the Creative Commons Attribution International License (CC BY 4.0).

http://creativecommons.org/licenses/by/4.0/

\begin{abstract}
An optimum design of box cuts in soil formations is very crucial in order to obviate the major risk factors originating from the collapse of sidewalls and flooding of excavations during storm rainfall. The present paper aims to present a holistic classification of the Kalahari Formation stratigraphy in Zone 5 and define engineering properties of each lithological unit, in order to establish a safe working design. For the present objectives, collection of data was carried out through logging core from selected geotechnical boreholes drilled within vicinity of the proposed Northern mine box cut. Hydrogeological assessments and feasibility studies within the purview of study region were also considered. Geotechnical logging parameters gathered on site were derived from the Rock Mass Rating system (RMR) for design requirements [1]. Input parameters and material characteristics taken from laboratory test results provided by KCM were incorporated in the analysis. The box cut slopes were modelled in "Rocscience software" for evaluation of safety factor using "limit equilibrium method". Slope optimization required the slope surface to be as steep as possible while maintaining an adequate factor of safety ranging from 1.5 - 1.8. For the box cut design with optimum safety, the recommended parameters are: stable slope angle $-35^{\circ}-40^{\circ}$; ramp angle $-8^{\circ}$, depth of pit -60 meters; bench width -4.9 meters and the bench length13.25 meters.
\end{abstract}

\section{Keywords}

Boxcut Slope, Slope Stability, Finite Element Analysis, Limit Equilibrium Analysis, Rocscience Software 


\section{Introduction}

Khoemacau Copper Mining Company (KCM) is located in the North Western part of Botswana along the Kalahari Copper Belt. It is subdivided into nine prospecting areas which cover a total area of $4041 \mathrm{~km}^{2}$ (Figure 1). The Zone 5 area is one of nine mining prospects for KCM situated in the "Ghanzi-Chobe Copper Belt". Zone 5 ore body dips at about $55^{\circ}$ to the east and extends for at-least 4.5 $\mathrm{km}$ in strike length, the ore body has been confirmed to extend to almost $1.2 \mathrm{~km}$ deep.

This type of ore body geometry requires extraction of the ore in levels going down. Sub level open stoping has been proposed as the preferred mining method for economic, safe and sustainable extraction of the ore body. The Kalahari Formation provides a $30 \mathrm{~m}$ thick cover which hampers easy access to the ore body, therefore, box cuts have been proposed from which declines will be developed to access the underground workings. The box cuts will be constructed on Kalahari Formation with the decline entrance located in the zone of the Ngwako Pan Sandstone [2] [3].

The Kalahari Formation is highly weathered and easily collapsible under load or when watered. All this taken into consideration has a potential of causing a major failure to the mine design. Therefore, it is critical to understand the engineering behaviour of the Formation in order to establish slope configurations that ensure mine stability.

\section{Stratigraphy}

The "Ghanzi-Chobe Copper Belt", which is part of "Kalahari Copper Belt" is defined by a succession of sedimentary and volcanic rocks deposited in Late $\mathrm{Me}$ soproterozoic and Early Neoproterozoic eras [4]. Deformation and metamorphism on the belt occurred during the Pan African "Damaran Orogeny". "Kgwebe Formation" forms basal unit of the belt and is overlain by Ghanzi Group (530 $\mathrm{Ma}$ - $1020 \mathrm{Ma}$ ) which consists of "Ngwako Pan", “D’Kar" and "Mamuno Formations" [5] (Figure 2).

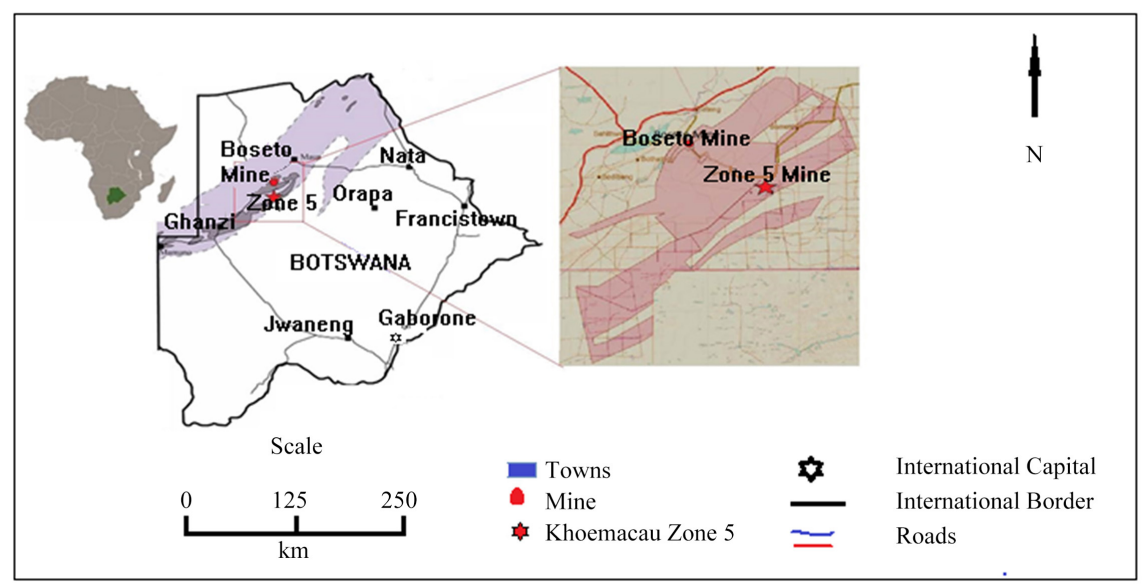

Figure 1. Location Map of Study Area. After Master (2010). 


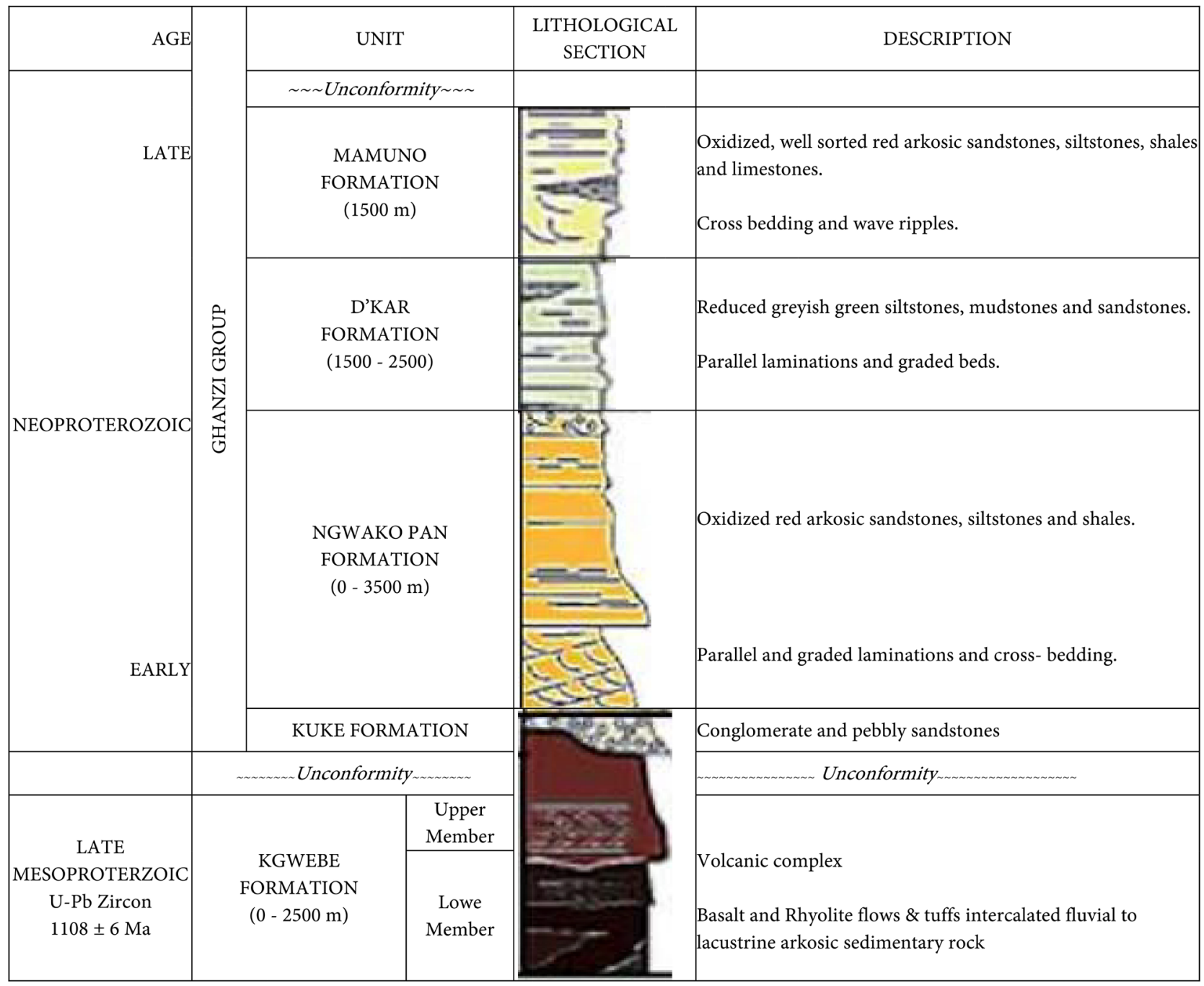

Figure 2. Stratigraphy of "Kgwebe Formation" and "Ghanzi Group” After Modie (2000).

\subsection{Kgwebe Formation}

Basin evolution in the Ghanzi-Chobe Belt occurred in stages that broadly correspond to the major depositional environments of the Kgwebe Formation the "Kgwebe Formation" represents the earliest stage of basin development that was initiated by extensional tectonics, which led to intracontinental rifting and subsequent bimodal volcanism, about $1106 \mathrm{Ma}$ ago. Sedimentation contemporaneous with volcanism resulted in the accumulation of sandstone and tuffitic siltstones of the Kgwebe Formation. "Kgwebe Formation" is $2500 \mathrm{~m}$ in thickness forming the unit consisting of Rhyolites, Dacites, Basalts and minor intercalated sedimentary rocks [5].

\subsection{Ngwako Pan Formation}

"Ngwako Pan Formation" locally known as NPF is approximately $2000 \mathrm{~m}$ thick and is underlain by a thin Sandstone with Conglomerate containing clasts from the underlying Kgwebe volcanics. The formation was deposited due to exten- 
sional faulting of the intercontinental basin which led to deposition of alluvial to lacustrine sediments.

\subsection{D'kar Formation}

"D'kar Formation" that conformably overlies "Ngwako Pan Formation" is approximately $1500 \mathrm{~m}$. This Formation consists of reduced fine grained Sandstones, oolitic Limestones and Marlstones. These rocks show parallel laminations and normally graded rhythmites. These are believed to have been deposited due to enlargement of the basin and a major marine transgression [5].

\subsection{Mamuno Formation}

"Mamuno Formation" lies at the top of the "Ghanzi Group" "Mamuno Formation", composed of reddish Sandstone, Mudstones, Siltstones and minor Limestone intraclasts. This Formation has not been intersected in Khoemacau Mining license area. According to [3] the Formation is characterized by cross bedding, planar parallel laminations and wave ripple structures suggesting nearshore to shoreline depositional environment.

\section{Structural Geology}

[6] suggests that there are fold units observed at the bottom of "D'Kar Formation". These fold units are asymmetrical and have a southeast inclination. Their asymmetry is evidenced by variations in thickness of the northwest and southeast limbs of these folds. These limbs have dips ranging from $45^{\circ}$ to $90^{\circ}$ and their axial planes strike $220^{\circ}$ and $235^{\circ}$ and dip between $80^{\circ}$ to the northwest and vertical. There is also a weakly developed foliation or cleavage observed in the region most especially in the fine-grained lithology like Marls and Siltstones, but no foliation is discovered in the Sandstones of "Ngwako Pan Formation" [3].

\section{Hydrogeology}

The Zone 5 site has a mean annual precipitation of $471 \mathrm{~mm}$ based on the rainfall information acquired for Maun (2009-2017) which is approximately $40 \mathrm{~km}$ north-east of the Project area. Between the years of 2014 and 2015, KCM conducted several hydrogeological assessments and feasibility studies. These studies allowed KCM to design a cost-effective and efficient dewatering system for the mine based on advanced planning of predicted mine inflows. From the studies it was found that the groundwater levels to the west of Zone 5 near the Kgwebe Hills were shallow and ranged between $26 \mathrm{~m}$ and $40 \mathrm{~m}$ below ground level, indicating a possible recharge zone. Borehole drilling data indicated that NPF Sandstones are poor aquifers and that the main aquifer in the Zone 5 mine area is the “D’Kar Formation”.

\section{Methodology}

The Northern mine box cut was picked as the focus of this study (Figure 3). The 
Geological logging data reviled the lithological units comprise of soil, sand, calcareous sand, sandy Calcrete and Sandstone (Figure 4) Laboratory tests of consolidated undrained triaxial test, direct shear and Uniaxial Compressive Strength with Young's Modulus and Poisson's Ratio were done for all lithological units.

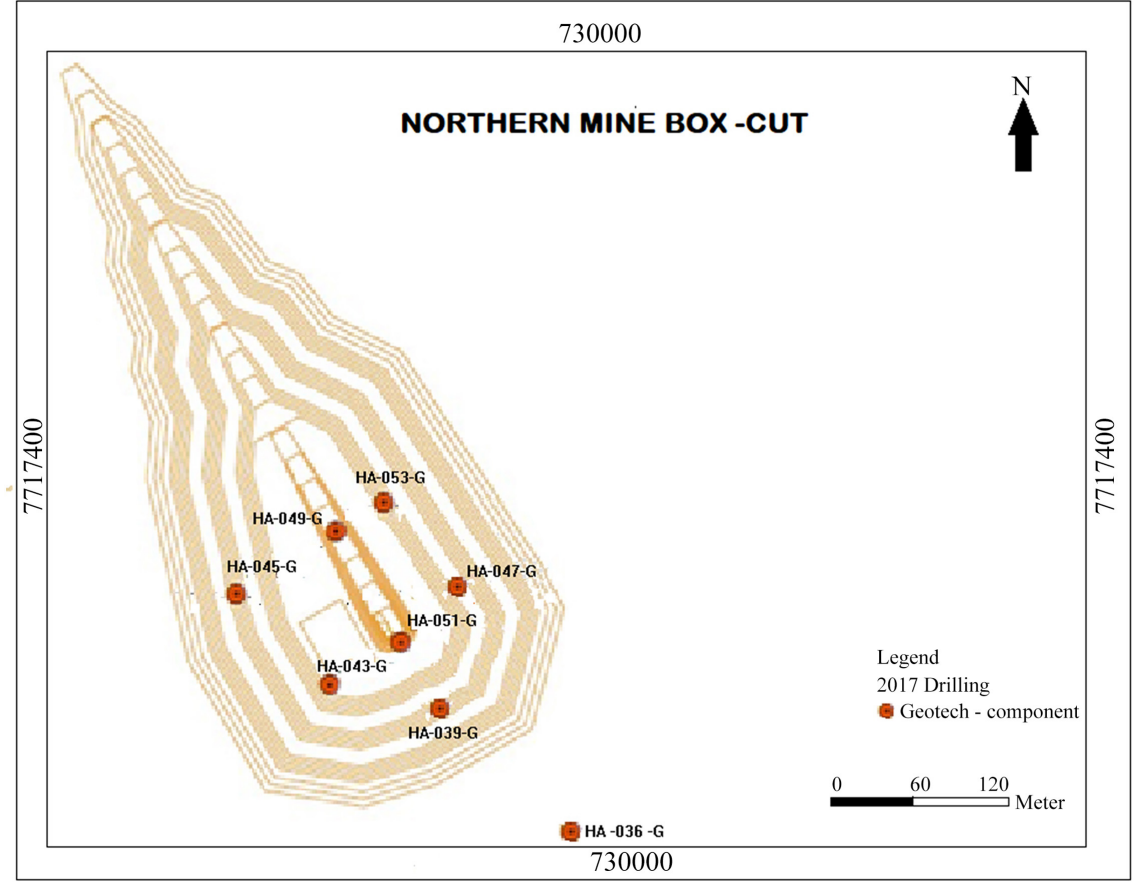

Figure 3. Proposed northern box cut in Zone 5 mine.

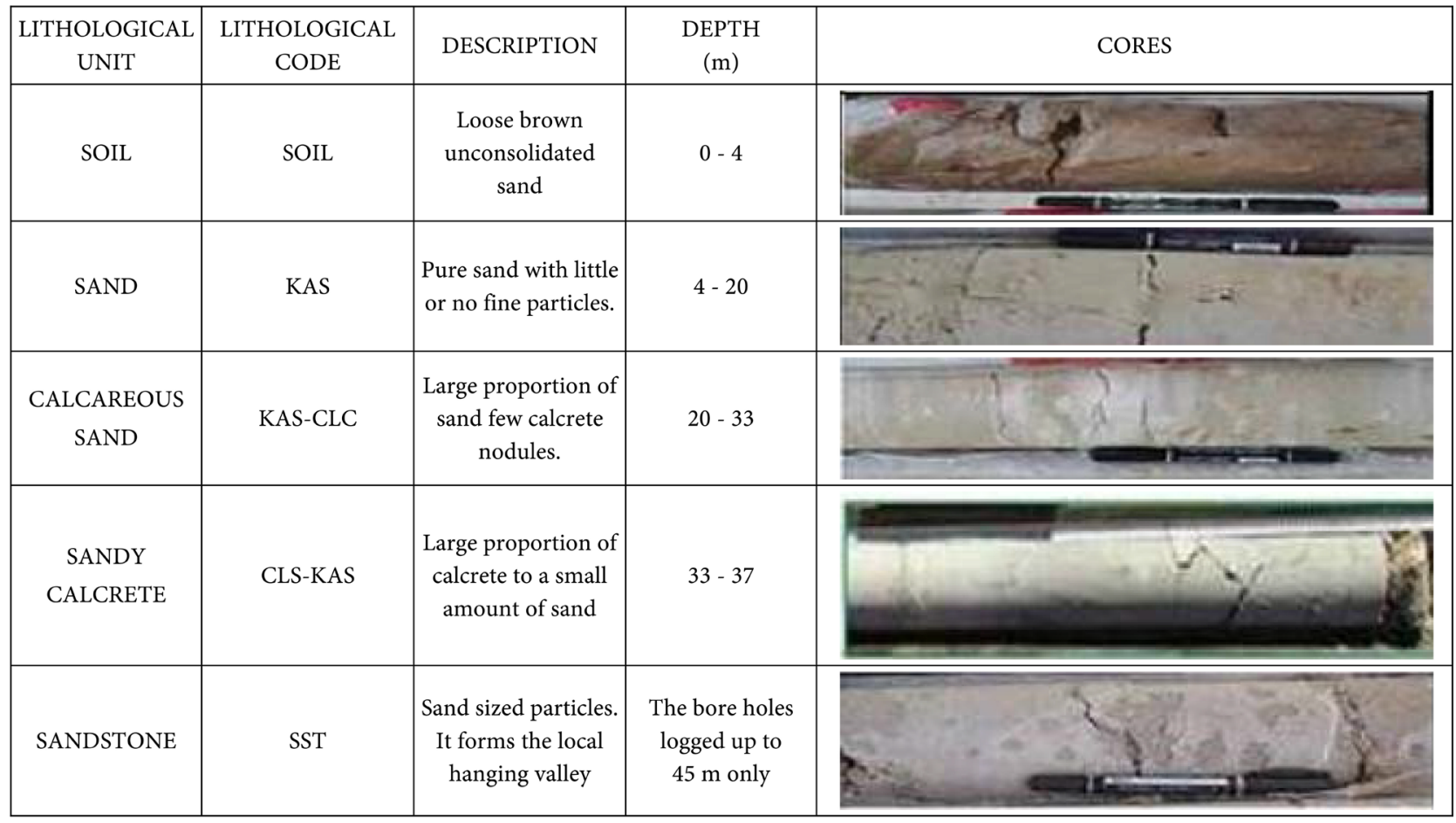

Figure 4. Stratigraphic units logged. 


\section{Modelling Slopes with Rs2 \& Slide 2018 Softwares}

With consideration to the height and width of the mining equipment and the size excavation the box cut slopes with dimensions provided in Table 1 were modelled in Slide 2018 software for evaluation of safety factor of slope failure surfaces using limit equilibrium method. The models were imported into RS2 and analysed by Shear Strength Reduction (SSR) method.

Input parameters and material characteristics (Table 2) were taken from the laboratory test results provided by KCM. To optimize the slope design, the slope surface was made as steep as possible while maintaining an adequate factor of safety ranging from 1.5 - 1.8 following the acceptance criteria for open pit slopes based on [7] (Table 3).

Table 1. Dimensions used to model the slopes in rocscience software.

\begin{tabular}{ccc}
\hline Parameter & Value \\
\hline Bench Width & $3 \mathrm{~m}$ \\
Bench Height & $13.25 \mathrm{~m}$ \\
Ramp angle & $8^{\circ}$ \\
\hline
\end{tabular}

Table 2. Input parameters for soil properties and finite element model.

\begin{tabular}{|c|c|c|c|c|c|c|c|}
\hline Lithological unit & $\begin{array}{c}\text { Unit } \\
\text { Weight } \\
\mathrm{KN} / \mathrm{m}^{3}\end{array}$ & Initial Element Loading & Failure Criterion & $\begin{array}{c}\text { Material } \\
\text { Type }\end{array}$ & $\begin{array}{c}\text { Cohesion } \\
\text { (Residual) } \\
\quad(\mathrm{kPa})\end{array}$ & $\begin{array}{l}\text { Friction } \\
\text { Angle } \\
\text { (residual) }\end{array}$ & $\begin{array}{c}\text { Dilation } \\
\text { Angle }\end{array}$ \\
\hline SOIL & 20.907 & Field stress and body force & Mohr-coulomb & plastic & 0.233 & $37.13^{\circ}$ & $0^{\circ}$ \\
\hline KAS & 20.165 & Field stress and body force & Mohr-coulomb & plastic & 11.05 & $34.35^{\circ}$ & $0^{\circ}$ \\
\hline KAS/CLC & 19.177 & Field stress and body force & Mohr-coulomb & plastic & 6.686 & $32.17^{\circ}$ & $0^{\circ}$ \\
\hline CLC/KAS & 20.410 & Field stress and body force & Mohr-coulomb & plastic & 7.5 & $34.25^{\circ}$ & $0^{\circ}$ \\
\hline SST & 26.066 & Field stress and body force & Mohr-coulomb & plastic & 11.133 & $35.25^{\circ}$ & $0^{\circ}$ \\
\hline BACKFILL MATERIAL & 26 & field stress \& body force & Mohr-coulomb & Plastic & 13 & $35^{\circ}$ & $0^{\circ}$ \\
\hline
\end{tabular}

Table 3. Design acceptance criteria for open pit slopes. After wesseloo \& read (2009).

\begin{tabular}{cccc}
\hline \multirow{2}{*}{ Slope scale } & Low & Consequences of failure & High \\
\cline { 2 - 4 } & & Medium & FoS $\geq 1.1$ \\
Bench & & PoF $\leq 25 \%-50 \%$ & FoS $\geq 1.2-1.3$ \\
& FoS $\geq 1.15-1.2$ & FoS $\geq 1.2$ & PoF $\leq 10 \%$ \\
Inter-ramp & PoF $\leq 25 \%$ & PoF $\leq 20 \%$ & FoS $\geq 1.3-1.5$ \\
& FoS $\geq 1.2-1.3$ & FoS $\geq 1.3$ & PoF $\leq 5 \%$ \\
\hline
\end{tabular}

FoS-Factor of safety; PoF-Probability of failure. 


\section{Results and Discussion}

Two methods were used during slide analysis, Bishop simplified method and Janbu simplified method while SSR method was used during RS2 analysis based on the Mohr Coulomb shear strength criterion. Different values of factor of safety attained for different slopes of the box cut are due to varying lithology.

[8] investigated the effects of spatially variable anisotropic soil fabric in a slope on its safety factor and failure mechanisms. [9] investigated the random nature of the geometric interfaces between soil and rock as a two-phase random medium. [10] examined the necessity of three-dimensional analysis when dealing with slope with full randomness in soil properties.

Table 4 shows that factor of safety increased with decreasing slope angles. Slope angles less than $35^{\circ}$ gave high factors of safety, greater than 1.8 which implies the slope will be overdesigned and costly. Optimum slope angle was at $35^{\circ}$ as the safety factors ranged from $1.5-1.8$ which are aligned with the acceptance criteria. Although an overall slope angle of $40^{\circ}$ gives an acceptable factor of safety, it is not considered optimum since the north east slope produced low factor of safety of about 1.3, which will not be adequate for the life of mine. Typical results from slide and RS2 showing critical SRF and FOS respectively for south West slope are shown in Figure 5(a) \& Figure 5(b).

Strength reduction factor also showed sensitivity to change in overall slope angle, the low slope angles of $30^{\circ}$ to $35^{\circ}$ gave higher SRF of 1.560 to 2.008 . The finite element analysis (FE) result was relatively higher than the limit equilibrium (LE) analysis but the deviations between both methods are negligible which validate the locations of failure surfaces.

Table 4. Results from Slide and Rs2.

\begin{tabular}{|c|c|c|c|c|}
\hline $\begin{array}{l}\text { OVERALL SLOPE } \\
\text { ANGLE }\end{array}$ & $\begin{array}{l}\text { ANALYSIS } \\
\text { PROGRAM }\end{array}$ & $\begin{array}{l}\text { SOUTH EAST } \\
\text { SLOPE }\end{array}$ & $\begin{array}{l}\text { NORTH EAST } \\
\text { SLOPE }\end{array}$ & $\begin{array}{l}\text { SOUTH WEST } \\
\text { SLOPE }\end{array}$ \\
\hline \multirow{4}{*}{$30^{\circ}$} & SLIDE: FoS & & & \\
\hline & Bishop Simplified & 2.052 & 1.964 & 2.008 \\
\hline & Janbu Simplified & 1.952 & 1.912 & 1.928 \\
\hline & RS2: SRF & 1.910 & 1.890 & 1.930 \\
\hline \multirow{4}{*}{$35^{\circ}$} & SLIDE: FoS & & & \\
\hline & Bishop Simplified & 1.838 & 1.647 & 1.642 \\
\hline & Janbu Simplified & 1.723 & 1.636 & 1.630 \\
\hline & RS2: SRF & 1.650 & 1.620 & 1.56 \\
\hline \multirow{4}{*}{$40^{\circ}$} & SLIDE: FoS & & & \\
\hline & Bishop Simplified & 1.696 & 1.363 & 1.433 \\
\hline & Janbu Simplified & 1.574 & 1.362 & 1.427 \\
\hline & RS2: SRF & 1.430 & 1.370 & 1.420 \\
\hline
\end{tabular}




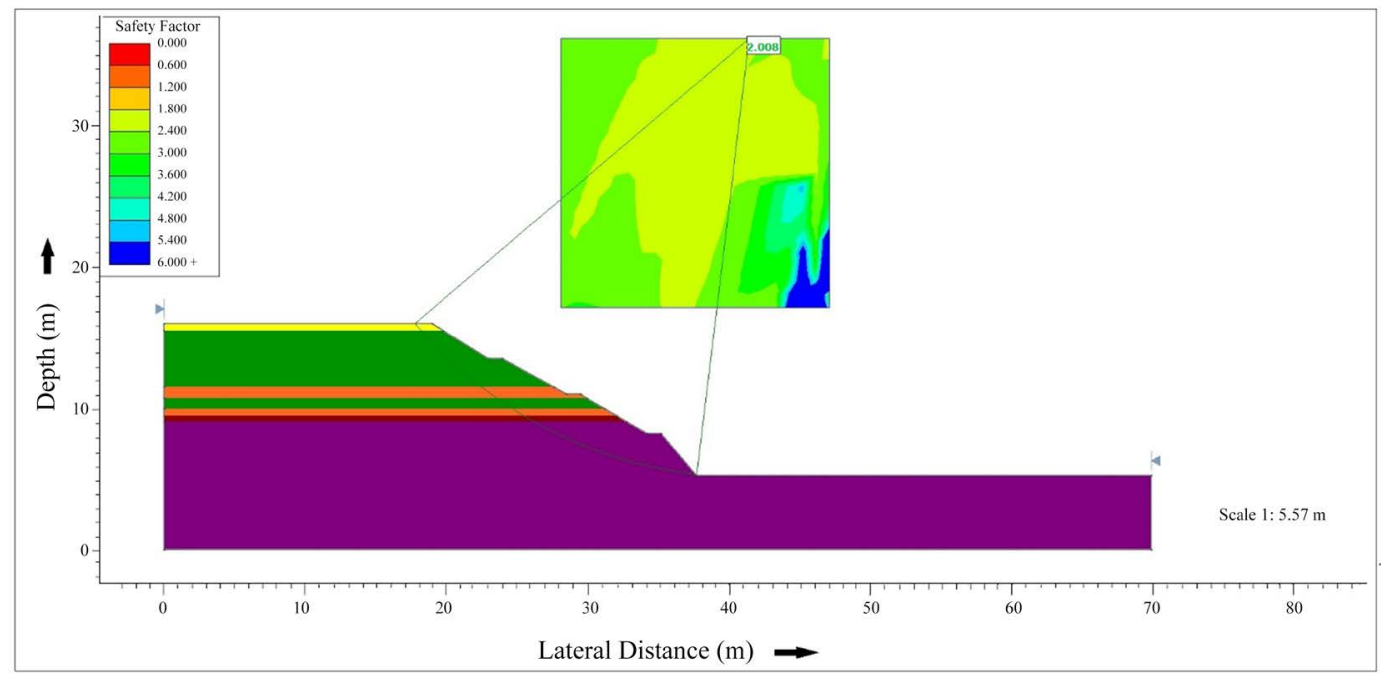

(a)

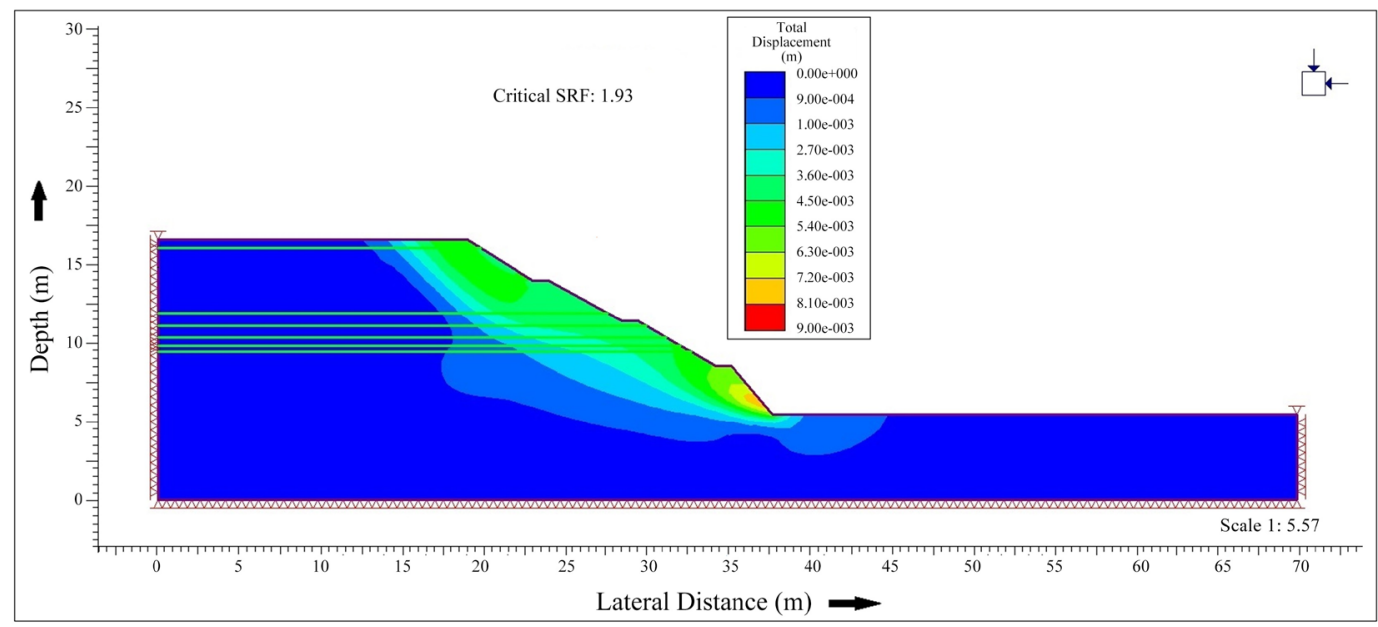

(b)

Figure 5. (a) Typical results from slide showing FOS for south west slope. (b) Typical results from Rs2 showing critical SRF for south west slope.

Excavation of the portal affects stability of the overall slope hence it is important to consider this in the design of the slope. A factor of safety of the portals has to be great enough to provide safe access for workers, material and equipment to the underground over a definable mine life. Following excavation of the portal, the overall slope failed hence a backfill material was used to reinforce and stabilize the slope. This backfill material will be in place of a lining to be used to support the portal. Typical results from slide and RS2 showing critical SRF and FOS respectively for south East slope with an excavated portal are illustrated in Figure 6(a) \& Figure 6(b).

The results in the Table 5 show that the FoS and SRF of the south east slope were higher due to the addition of a portal that was reinforced with backfill. Without support, the presence of the portal reduces the convergence of the material around the tunnel which reduces the overlying slope's stability. 


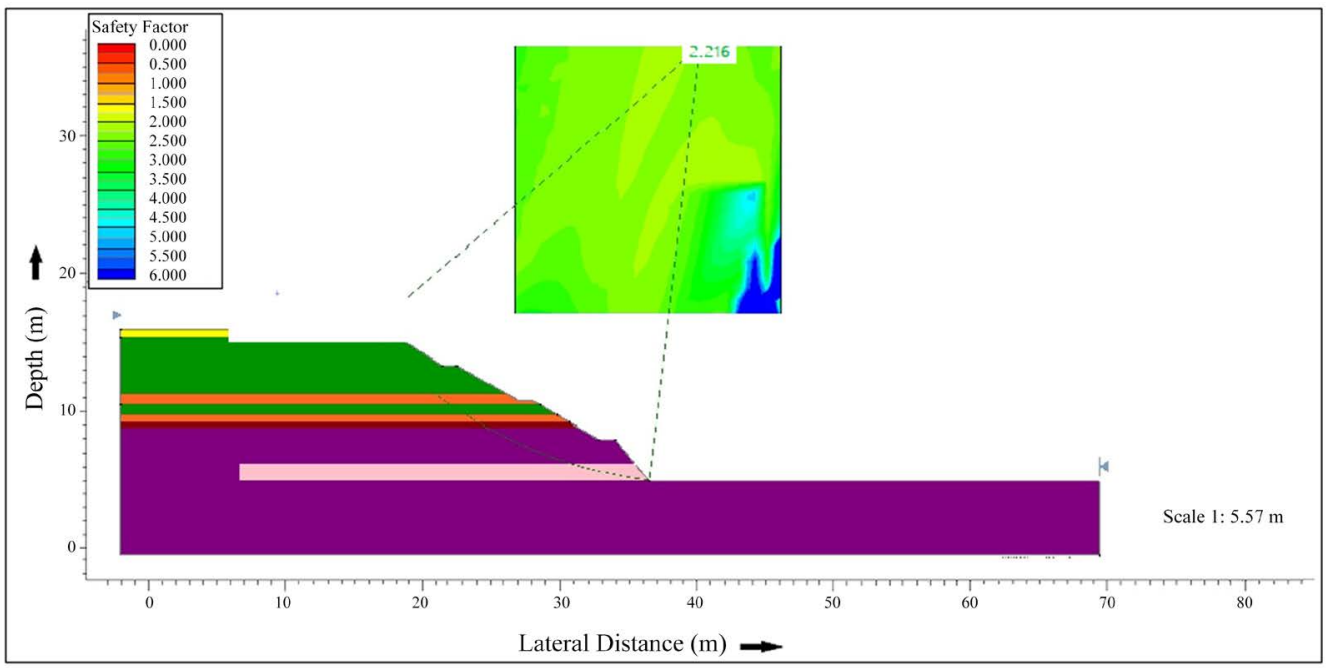

(a)

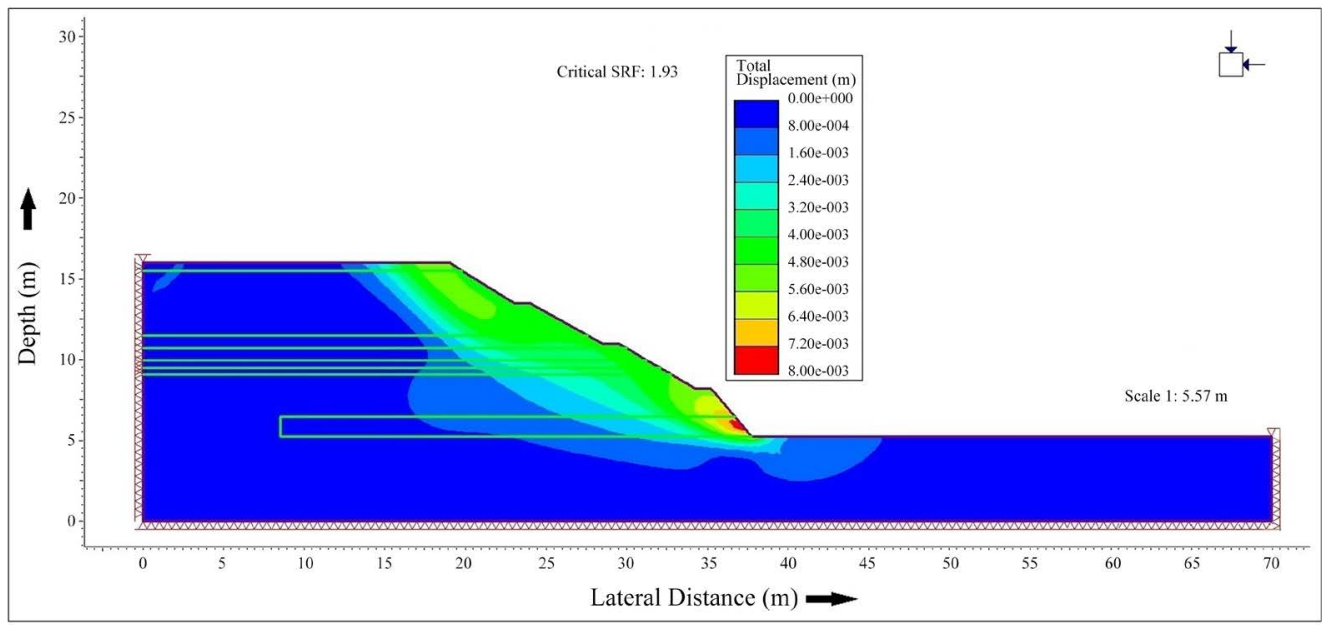

(b)

Figure 6. (a) Typical results from slide showing FOS for south east slope with excavated portal. (b) Typical results from Rs2 showing critical SRF for south east slope with excavated portal.

Table 5. Results from slide and Rs2 for the south east slope with a portal.

\begin{tabular}{|c|c|c|}
\hline SLOPE ANGLE & ANALYSIS & \\
\hline \multirow{4}{*}{$30^{\circ}$} & \multicolumn{2}{|c|}{ SLIDE: FoS } \\
\hline & Bishop Simplified & 2.235 \\
\hline & Janbu Simplified & 2.091 \\
\hline & RS2: SRF & 2.080 \\
\hline \multirow{4}{*}{$35^{\circ}$} & \multicolumn{2}{|c|}{ SLIDE: FoS } \\
\hline & Bishop Simplified & 1.976 \\
\hline & Janbu Simplified & 1.853 \\
\hline & RS2: SRF & 1.820 \\
\hline \multirow{4}{*}{$40^{\circ}$} & \multicolumn{2}{|c|}{ SLIDE: FoS } \\
\hline & Bishop Simplified & 1.761 \\
\hline & Janbu Simplified & 1.629 \\
\hline & RS2: SRF & 1.630 \\
\hline
\end{tabular}




\section{Conclusion}

Based on the present study, the following conclusions have been drawn:

- Slope angles ranging from $35^{\circ}-40^{\circ}$ will be optimum slope angles with safety factors ranging from $1.5-1.8$.

- With the suggested optimum angles, an economic box cut design can be achieved without compromising safety.

- Support and reinforcement of the portal are mandatory to ensure stability.

\section{Recommendations}

Based on geotechnical analysis of the study area we recommend the box cut design parameters to be as follows;

- Overall slope angle: $35^{\circ}-40^{\circ}$.

- Ramp angle: $8^{\circ}$.

- Depth of pit: 60 meters.

- Bench width: 4.9 meters.

- Bench length: 13.25 meters.

To prevent the collapse of side walls we recommend spraying $300 \mathrm{~mm}$ thick Shotcrete into wire mesh. The backfill material used for analysis suggests that, a $50 \mathrm{MP}$ concrete lining with a minimum thickness of $250 \mathrm{~mm}$ with additional steel reinforcement is recommended for overburden depths of up to $80 \mathrm{~m}$ to support the portal.

\section{Acknowledgements}

The authors are thankful to Department of Mining and Geological Engineering, BIUST, for providing the infrastructural and laboratory facilities and resources to make this work possible and Khoemacau Copper Mining (Pty) Ltd for allowing us to conduct a study on their site/project.

\section{Conflicts of Interest}

The authors declare no conflicts of interest regarding the publication of this paper.

\section{References}

[1] Bieniawski, Z.T. (1989) Engineering Rock Mass Classifications: A Complete Manual for Engineers and Geologists in Mining, Civil and Petroleum Engineering. Wiley, New York.

[2] Gill, S.J. (2011) The Kalahari Copperbelt in Central-Eastern Namibia. University of London, London.

[3] Hall, W.S. and Wesley, S. (2013) Geology and Paragenesis of the Boseto Copper Deposit, Kalahari Copperbelt, Northwest Botswana. Colorado School of Mines, Colorado.

[4] Master, S. (2010) Hana Mining Ltd Copper Concessions in The Ghanzi-Chobe Belt of Ngamiland, Botswana. University of Witwatersand, Johannesburg.

[5] Modie, B.N. (2000) Geology and Mineralisation in the Meso-to Neoproterozoic 
Ghanzi-Chobe Belt of Northwest BOTSWANA. Journal of Africa Earth Sciences, 30, 467-474. https://doi.org/10.1016/S0899-5362(00)00032-4

[6] Davies, B. (2013) Ghanzi Project, an Overview of The District Geological Framework \& Trap Site Structure. Renaissance Geology Ltd Pty, Perth.

[7] Wesseloo, J. and Read, J. (2009) Acceptance Criteria Guidelines for Open Pit Slope Design. CSIRO Publishing, Clayton.

[8] Zhu, H., Zhang, L.M. and Xiao, T. (2019) Evaluating Stability of Anisotropically Deposited Soil Slopes. Canadian Geotechnical Journal, 56, 753-760. https://doi.org/10.1139/cgj-2018-0210

[9] Liu, Y., Zhang, W.G., Zhang, L., Zhu, Z.R., Hu, J. and Wei, H. (2018) Probabilistic Stability Analyses of Undrained Slopes by 3D Random Fields and Finite Element Methods. Geoscience Frontiers, 9, 1657-1664. https://doi.org/10.1016/j.gsf.2017.09.003

[10] Liu, Y., Xiao, H.W., Yao, K., Hu, J. and Wei, H. (2018) Rock-Soil Slope Stability Analysis by Two-Phase Random Media and Finite Elements. Geoscience Frontiers, 9, 1649-1655. https://doi.org/10.1016/j.gsf.2017.10.007 